\title{
Congenital hyperreninemic hypoaldosteronism due to aldosterone synthase deficiency type I in a Portuguese patient - Case report and review of literature
}

1 Endocrinology, Diabetes and Metabolism Department, Coimbra Hospital and University Center, Coimbra, Portugal 2 Pediatric Unit, Coimbra Hospital and University Center, Coimbra, Portugal ${ }^{3}$ Pediatric Endocrinology Unit, Coimbra Hospital and University Center, Coimbra, Portugal

Correspondence to: Adriana de Sousa Lages Praceta Prof. Mota Pinto 3000-075 - Coimbra, Portugal adrianamslages@gmail.com

Received on Fev/20/2018 Accepted on Nov/14/2018

DOI: 10.20945/2359-3997000000107:

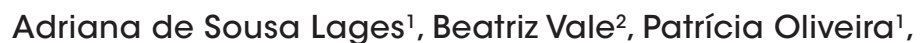
Rita Cardoso ${ }^{3}$, Isabel Dinis ${ }^{3}$, Francisco Carrilho', Alice Mirante ${ }^{3}$

\begin{abstract}
SUMMARY
Hyperreninemic hypoaldosteronism due to aldosterone synthase (AS) deficiency is a rare condition typically presenting as salt-wasting syndrome in the neonatal period. A one-month-old Portuguese boy born to non-consanguineous parents was examined for feeding difficulties and poor weight gain. A laboratory workup revealed severe hyponatremia, hyperkaliaemia and high plasma renin with unappropriated normal plasma aldosterone levels, raising the suspicion of AS deficiency. Genetic analysis showed double homozygous of two different mutations in the CYP11B2 gene: p.Glu198Asp in exon 3 and p.Val386Ala in exon 7. The patient maintains regular follow-up visits in endocrinology clinics and has demonstrated a favourable clinical and laboratory response to mineralocorticoid therapy. To our knowledge, this is the first Portuguese case of AS deficiency reported with confirmed genetic analysis. Arch Endocrinol Metab. 2019;63(1):84-8
\end{abstract}

\section{INTRODUCTION}

A ldosterone is a mineralocorticoid hormone secreted exclusively in the zona glomerulosa $(\mathrm{ZG})$ of the adrenal cortex and acts in distal renal tubules by increasing sodium reabsorption and promoting urinary potassium excretion. The aldosterone synthesis is dependent on aldosterone synthase (AS), an enzyme encoded by the CYP11B2 gene, one of the cytochrome $\mathrm{P} 450$ enzymes (P450cl1Aldo). AS, previously named corticosterone methyloxidase is expressed in the adrenal cortex and is responsible for catalysing the final three steps of the aldosterone biosynthesis: from 11-desoxycorticosterone (DOC) to corticosterone, then to 18-hidroxicorticosterone (18-OHB) and finally to aldosterone $(1,2)$.

Congenital hyperreninemic hypoaldosteronism due to defects in AS caused by inactivating mutations in the CYP11B2 gene has an unknown prevalence and is usually associated with an autosomal recessive pattern of inheritance. Two distinct forms of AS deficiency have been described, type I and type II, based only on the biochemical profile: no AS catalytic activity and low 18-hydroxycorticosterone (18-OHB) levels in AS deficiency type I and residual enzymatic catalytic activity and elevated 18-OHB levels in AS deficiency type II (3).

Typically, the disease manifests in the first weeks of life with nausea, vomiting, feeding problems and failure to thrive in the neonatal period. Isolated aldosterone deficiency is associated with neonatal salt-wasting syndrome resulting in hyponatremia, hyperkalaemia, metabolic acidosis and marked elevated renin with low or unappropriated normal aldosterone levels (4-15). Usually, clinical severity improves with age and patients are frequently asymptomatic during adulthood despite not having mineralocorticoid therapy (16).

Most of the cases reported in the literature are from Iranian Jewish patients $(5,16,17)$, but cases from Turkey $(14,18)$, Japan $(7,8)$ and Israel $(9,19)$ have also been described. To our knowledge, there has been no 
previous report of Portuguese cases of AS deficiency, especially with confirmed genetic analysis.

\section{CASE PRESENTATION}

We report a case of a one-month-old infant delivered by caesarean section at 35 weeks from a dichorionic diamniotic twin pregnancy with a birth weight of $2,350 \mathrm{~g}$ and a length of $46 \mathrm{~cm}$. The parents are Portuguese and non-consanguineous.

Our patient presented l-week complaints of an increased number of dejections and vomiting predominantly after feeding. At the first examination in a local paediatric hospital, he presented severe signs of dehydration (heart rate $160 \mathrm{bpm}$, blood pressure $92 / 58 \mathrm{mmHg}$, abnormally prolonged capillary refill time, deeply sunken eyes, mottled extremities), failure to retrieve weight compared to birth weight $(2,340 \mathrm{~g})$ and marked hypotonia. He had a normal male phenotype with no genital anomalies, and no skin hyperpigmentation was described. A laboratory examination revealed an elevated plasma potassium level of $7.4 \mathrm{mmol} / \mathrm{L}$ [normal range (NR) 3.5-5.1], a low plasma sodium level of $126 \mathrm{mmol} / \mathrm{L}$ (NR 137 145) and metabolic acidosis ( $\mathrm{pH} 7.16$ pCO2 46 $\mathrm{mmHg} \mathrm{HCO} 316.4 \mathrm{mmol} / \mathrm{L}$ Lactates $5.3 \mathrm{mmol} / \mathrm{L}$ Anion Gap - $13.6 \mathrm{mmol} / \mathrm{L})$. Prompt therapy with 5\% dextrose and $0.45 \%$ sodium chloride $(\mathrm{NaCl})$ as well as infusion of sodium bicarbonate were initiated, and the patient was transferred to our central medical unit.

During the hospital admission, because of a clinical presumptive diagnose of congenital adrenal hyperplasia, he was given therapy with hydrocortisone $(2.5 \mathrm{mg}$ $6 / 6 \mathrm{~h})$ and oral $\mathrm{NaCl}$ supplement $(0.8 \mathrm{mEq} / \mathrm{kg} /$ day $)$ with initial favourable clinical and laboratory response.

However, a hormonal workup revealed normal plasma levels of adrenocorticotropic hormone (ACTH) (11.8 $\mathrm{pg} / \mathrm{mL}-\mathrm{NR}<46)$, cortisol $(10.9 \mu \mathrm{g} / \mathrm{dL}$ - NR 5.0-25.0), 17-OH-progesterone (17-OHP) $(10.0 \mathrm{ng} / \mathrm{mL})$, androstenedione $(0.9 \mathrm{ng} / \mathrm{mL})$ and dehydroepiandrosterone sulfate (DHEA-SO4) (32.5 $\mu \mathrm{g} / \mathrm{dL}$ ) with marked elevated renin (> $500 \mu \mathrm{UI} / \mathrm{mL}$ ) levels and unappropriated normal aldosterone [12.4 $\mathrm{ng} / \mathrm{dL}$; measured by chemiluminescent immunoassay (CLIA) on Liaison $^{\circledast}$ ], ruling out the first clinical suspicion of congenital adrenal hyperplasia $(\mathrm{CAD})$ and raising the suspicion of primary hypoaldosteronism as the probable cause of the severe neonatal salt-wasting syndrome (Table 1). Ultrasound investigation of the kidneys revealed no abnormalities, and there were no signs of enteropathy, urinary tract infection or obstruction.

The patient was discharged with an oral $20 \% \mathrm{NaCl}$ supplement $(0.4 \mathrm{~mL}, 8$ times/day after feeding) and ion-exchange resin - sodic phase ( $1.8 \mathrm{~g}, 3$ times/day). At 54 days old, he had his first paediatric endocrinology appointment with new laboratory evaluation, confirming the results previously obtained and maintenance of an elevated plasma potassium level of $5.95 \mathrm{mmol} / \mathrm{L}$ (NR $3.5-5.1)$, so therapy with fludrocortisone $(0.075 \mathrm{mg} /$ day, $0.018 \mathrm{mg} / \mathrm{kg} /$ day) and $\mathrm{NaCl}$ supplementation were associated.

Genetic analysis was performed with direct DNA sequence analysis of the entire coding regions of the CYP11B2 gene and revealed that our patient is a doublehomozygous carrier of two mutations: in exon 3 , codon 198 with replacement of glutamic acid for aspartic acid - c.594A > C (p.Glu198Asp), and in exon 7, codon 386 with replacement of valine for alanine - c.1157T > C (p.Val386Ala). Genotyping of these variations in both parents revealed that both were heterozygous carriers of the same two mutations, c.594A > C (p.Glu198Asp) and c.1157T > C (p.Val386Ala) - mutation in cis which implies a $25 \%$ risk of AS deficiency in offspring.

The patient maintains regular follow-up visits to endocrinology clinics, is currently 5 years old and good clinical effect on body growth and normalization of laboratory abnormalities after introduction of mineralocorticoid therapy. The dose of oral fludrocortisone has been stable at $0.075 \mathrm{mg} /$ day, in two divided doses.

\section{DISCUSSION}

Aldosterone is secreted on the $\mathrm{ZG}$ of the adrenal gland under control of three principal factors: angiotensin II, potassium and, to a lesser extent, ACTH. The first two secretagogues stimulate aldosterone secretion mainly by increasing the transcription of the CYPIIB2 gene. Distinctly, ACTH acutely stimulates the early pathways of adrenal steroidogenesis, promoting a $10 \%-20 \%$ elevation of the aldosterone circulating levels (20).

Mineralocorticoid deficiency can be divided in two categories: congenital and acquired syndromes.

Mutations in the gene encoding the AS enzyme, exclusively found in the $Z \mathrm{ZG}$, are associated with isolated mineralocorticoid deficiency. Nevertheless, functional mineralocorticoid deficiency may also be related to mutations in the mineralocorticoid receptor or in the 
gene encoding the epithelial sodium channel $(\mathrm{ENaC})$ (21).

Regarding primary defects in aldosterone biosynthesis, mutations in AS limit the activation of DOC to aldosterone through three terminal subsequent steps catalysed by the mitochondrial CYP enzyme 11B2 (CYP11B2). Patients with AS deficiency can be classified as type I or type II according to the variable biochemical phenotype (based on 18-OHB and aldosterone levels). Both cases are rare and are inherited in an autosomal recessive pattern (3).

Our patient presented with severe salt-wasting syndrome with important signs and symptoms of dehydration, feeding difficulties and failure to thrive in the neonatal period. Clinical presentation along with a typical biochemical profile with hyponatremia, hyperkalaemia, normal cortisol and sex steroids, high plasma renin levels and unappropriated normal aldosterone levels suggested the underlying diagnosis, posteriorly confirmed by genetic analysis of CYPI1B2 gene mutations on the index case.

In the neonatal period, clinical presentation can be dramatic, with significant hemodynamic impact and life-threating episodes of seizure and coma. Typically, we assist an improving of clinical severity with age, and adults are frequently asymptomatic despite no mineralocorticoid therapy. This fact can be associated with a gradual declining dependency on aldosterone during lifetime for normal ionic imbalance due to possible extra-adrenal compensatory mechanisms and alternative ACTH-dependent pathways for mineralocorticoid biosynthesis (22).

Occasionally, during adulthood, patients can present with orthostatic hypotension and hyperkalaemia in particular situations (as dehydration and heat stroke). A complete past medical history, with detailed childhood development and other medical conditions associated (such as nausea, vomiting, feeding problems and deficit

Table 1. Initial and sequential plasma levels (ionogram and hormonal profile) in Portuguese patient with congenital hyperreninemic hypoaldosteronism due to aldosterone synthase deficiency

\begin{tabular}{|c|c|c|c|c|c|c|c|c|}
\hline & $\begin{array}{c}\text { 13/10/2012 } \\
\text { presentation }\end{array}$ & 5/11/2012 & 13/12/2013 & $02 / 01 / 2014$ & 7/10/2014 & 21/4/2016 & 13/3/2018 & $\begin{array}{c}\text { Normal } \\
\text { range }\end{array}$ \\
\hline Weight (g) & 2,340 & 2,980 & 4,240 & 4,740 & 10,100 & 12,900 & 17.400 & \\
\hline Height (cm) & 46 & & 56 & 57.5 & 78.5 & 95.1 & 106.4 & \\
\hline Age & 31 days & 54 days & 91 days & 110 days & 18 months & $\begin{array}{c}3 \text { years }+7 \\
\text { months }\end{array}$ & $\begin{array}{c}5 \text { years }+6 \\
\text { months }\end{array}$ & \\
\hline \multicolumn{9}{|l|}{$\begin{array}{l}\text { Basal plasma } \\
\text { levels }\end{array}$} \\
\hline $\mathrm{Na}^{+}(\mathrm{mmol} / \mathrm{L})$ & 126 & 140 & 141 & 139 & 140 & 142 & 140 & $137-145$ \\
\hline $\mathrm{K}^{+}(\mathrm{mmol} / \mathrm{L})$ & 7.4 & 5.95 & 5.49 & 4.61 & 4.06 & 4.39 & 4.1 & $3.5-5.1$ \\
\hline ACTH (pg/mL) & 11.8 & & & & & & & $<46.0$ \\
\hline $\begin{array}{l}\text { Basal cortisol } \\
(\mu \mathrm{g} / \mathrm{dL})\end{array}$ & 10.9 & & & & & & & $5.0-25.0$ \\
\hline $\begin{array}{l}\text { Basal 17-0HP } \\
(\mathrm{ng} / \mathrm{mL})\end{array}$ & 10.0 & & & & & & & \\
\hline $\begin{array}{l}\operatorname{Renin}(\mu \mathrm{U} / / \mathrm{mL}) \\
(\mathrm{UU} / \mathrm{mL})\end{array}$ & $>500$ & $>500$ & 208.2 & 26.5 & 0.5 & 1.9 & 0.5 & $\begin{array}{c}1.0-16.0 \\
7-76\end{array}$ \\
\hline $\begin{array}{l}\text { Aldosterone } \\
(\mathrm{ng} / \mathrm{dL})(\mathrm{pg} / \mathrm{mL})\end{array}$ & 12.4 & 9.8 & 6.4 & 1.1 & 1.2 & 16.2 & 24.6 & $\begin{array}{c}2.8-39.9 \\
40-310\end{array}$ \\
\hline $\begin{array}{l}\text { Free testosterone } \\
(\mathrm{pg} / \mathrm{mL})\end{array}$ & 2.81 & & & & & & & \\
\hline $\begin{array}{l}\text { Androstenedione } \\
(\mathrm{ng} / \mathrm{mL})\end{array}$ & 0.9 & & & & & & & \\
\hline DHEA-SO$_{4}(\mu \mathrm{g} / \mathrm{dL})$ & 32.5 & & & & & & & \\
\hline Therapy & - & $\begin{array}{l}\text { Oral } 20 \% \\
\quad \mathrm{NaCl} ; \\
\text { Exchange } \\
\text { resin sodic } \\
\text { phase }\end{array}$ & $\begin{array}{c}\text { Oral } 20 \% \mathrm{NaCl} \\
\text { supplement; } \\
\text { Fludrocortisone } \\
0.05+ \\
0.025 \mathrm{mg}\end{array}$ & $\begin{array}{c}\text { Oral } 20 \% \mathrm{NaCl} \\
\text { supplement; } \\
\text { Fludrocortisone } \\
0.05+ \\
0.025 \mathrm{mg}\end{array}$ & $\begin{array}{c}\text { Oral } 20 \% \mathrm{NaCl} \\
\text { supplement; } \\
\text { Fludrocortisone } \\
0.05+ \\
0.025 \mathrm{mg}\end{array}$ & $\begin{array}{c}\text { Fludrocortisone } \\
0.05+ \\
0.025 \mathrm{mg}\end{array}$ & $\begin{array}{c}\text { Fludrocortisone } \\
0.05+ \\
0.025 \mathrm{mg}\end{array}$ & \\
\hline
\end{tabular}

ACTH: adrenocorticotropic hormone; 17-OHP: 17-OH-progesterone; DHEA-SO : dehydroepiandrosterone sulfate. 
in weight gain), is essential to identify the correct diagnosis $(1,16,23)$.

It is also important to establish a correct differential diagnose with another neonatal salt-wasting syndromes such as congenital adrenal hyperplasia $(\mathrm{CAH})$. In the latter, besides the clinical similarity at presentation, patients frequently have genital abnormalities (clitoral hypertrophy, labia partially or completely fused in girls) and a hormonal profile that is clearly distinct - instead of an isolated aldosterone deficiency with exclusively mineralocorticoid deficiency, on most patients (>95\%) with CAD due to 21-hydroxylase deficiency (CYP21A2), we found a combined aldosterone and cortisol synthesis deficiency associated with raised 17 $\mathrm{OHP}$, with elevated adrenal androgens as a hallmark of the diagnosis (24). Within this line, the therapy strategy is different and must include life-long glucocorticoid and mineralocorticoid replacement (16).

Typically, patients with AS deficiency respond well to fludrocortisone therapy and may also benefit from salt supplementation specifically in the neonatal period. In our patient, $\mathrm{NaCl}$ supplementation was discontinued at 2 years of age, and maintenance of mineralocorticoid therapy with fludrocortisone in a stable dose of 0.075 $\mathrm{mg}$ allowed a catch-up growth with a favourable clinical and biochemical response.

Generally, genetic analysis of AS deficiency cases identified mutations on the CYPIIB2 gene. Our patient is a double-homozygous carrier for two sequence changes leading to amino acid substitutions: E198D in exon 3 and V386A in exon 7. Both parents are heterozygous carriers for the same two mutations, which justifies the fact that neither have any clinical manifestation of the disease - mutation in cis. The combination of these two mutations encodes enzymes with a reduced residual $11 \beta$-hydroxylase activity; however, with no broad catalytic activity, the clinical phenotype arises (25).

Although most cases of AS deficiency reported a mutation on the CYPBIIB2 gene, this condition has recently been associated with cases of patients with clinically and biochemically presumed AS deficiency with no identified mutations on the CYP11B2 gene, emphasising a bigger heterogeneity and possible other mechanisms associated with the disease - mutations in genes encoding other renin-aldosterone system components (such as angiotensinogen, angiotensinconverting enzymes and angiotensin II-receptor) or other regulatory genes of AS function. Encouraging the report of cases not linked to the CYPB11B2 gene mutations is important precisely to estimate the proportion of patients without positive genetic analysis and contribute to a broad comprehension of the molecular basis of the condition $(6,9)$.

Unfortunately, in our country, we did not have access to measurement of plasma or urinary $18-\mathrm{OHB}$ levels and corticosterone levels that clearly distinguish AS deficiency type I from type II. However, the genetic analysis and similarity to the genetic profile previously described by Portrat-Doyen S. and cols. together with the patient's clinical presentation strongly supported the diagnosis of AS deficiency type I for the first time in a Portuguese patient (25).

\section{CONCLUSIONS}

AS deficiency is a rare case of hyperreninemic hypoaldosteronism inherited in an autosomal recessive pattern. This condition represents a disorder of terminal biosynthesis of aldosterone with a typical manifestation of salt-wasting disorder in early life. Proper diagnosis of AS deficiency is essential for correct lifelong management, and genetic confirmation of CYPIIB2 mutation allows for evaluation of familial adult members, information regarding the implications on offspring and reducing potential life-threatening risks associated with the disease.

This is the first report of a Portuguese patient with presumed AS deficiency type I in whom the molecular basis has been clarified, matching the clinical and laboratory diagnosis initially suspected.

Mineralocorticoid therapy allowed remarkable weight recovery and total resolution of the initial symptoms and laboratory abnormalities. Expectedly, during adulthood, these patients present a favourable clinical course despite no fludrocortisone therapy and may only show an asymptomatic persistent abnormal steroid pattern throughout life.

Acknowledgments: the authors thank Dr. Ana Gabaral and Dr. Joaquim de Sá for the genetic evaluation and counselling of the patient and his family, as well as the Galician Foundation of Genomic Medicine (Santiago de Compostela, Spain) for the molecular study.

Funding statement: the authors declare that no funding was received for this publication.

Disclosure: no potential conflict of interest relevant to this article was reported. 


\section{REFERENCES}

1. Hui E, Yeung MC, Cheung PT, Kwan E, Low L, Tan KC, et al. The clinical significance of aldosterone synthase deficiency: report of a novel mutation in the CYP11B2 gene. BMC endocrine disorders. 2014;14(1):29.

2. Root AW. Disorders of aldosterone synthesis, secretion, and celIular function. Curr Opin Pediatr. 2014;26(4):480-6.

3. White PC. Aldosterone synthase deficiency and related disorders. Mol Cell Endocrinol. 2004;217(1):81-7.

4. Collinet E, Pelissier P, Richard O, Gay C, Pugeat M, MorelY, et al. [Four cases of aldosterone synthase deficiency in childhood]. Arch Pediatr. 2012;19(11):1191-5.

5. Katznelson D, Sack J, Kraiem Z, Lunenfeld B. Congenital hypoaldosteronism. Thirteen year follow-up in identical twins. Horm Res. 1979;11(1):22-8.

6. Kayes-Wandover KM, Tannin GM, Shulman D, Peled D, Jones KL, Karaviti $L$, et al. Congenital hyperreninemic hypoaldosteronism unlinked to the aldosterone synthase (CYP11B2) gene. J Clin Endocrinol Metabol. 2001;86(11):5379-82.

7. Kondo E, Nakamura A, Homma K, Hasegawa T, Yamaguchi T, Narugami $\mathrm{M}$, et al. Two novel mutations of the CYP11B2 gene in a Japanese patient with aldosterone deficiency type 1. Endocr J. 2013;60(1):51-5.

8. Kuribayashi I, Kuge $H$, Santa RJ, Mutlaq AZ, Yamasaki N, Furuno T, et al. A missense mutation (GGC [435Gly] $\rightarrow$ AGC [Ser]) in exon 8 of the CYP11B2 gene inherited in Japanese patients with congenital hypoaldosteronism. Hormone Res. 2003;60(5):255-60.

9. Leshinsky-Silver E, Landau Z, Unlubay S, Bistrizer T, Zung A, Tenenbaum-Rakover $Y$, et al. Congenital hyperreninemic hypoaldosteronism in Israel: sequence analysis of CYP11B2 gene. Hormone Res. 2006;66(2):73-8.

10. Peter M, Sippell WG. Congenital hypoaldosteronism: the VisserCost syndrome revisited. Pediatr Res. 1996;39(3):554-60.

11. Peter M, Nikischin W, Heinz-Erian P, Fussenegger W, Kapelari K, Sippell W. Homozygous deletion of arginine-173 in the CYP11B2 gene in a girl with congenital hypoaldosteronism. Corticosterone methyloxidase deficiency type II. Horm Res. 1998;50(4):222-5.

12. Peter M, Bunger K, Drop S, Sippell WG. Molecular genetic study in two patients with congenital hypoaldosteronism (types I and II) in relation to previously published hormonal studies. Eur J Endocrinol. 1998;139(1):96-100.

13. Rubio-Cabezas O, Regueras L, Muñoz-Calvo M, Bartolomé M, Pozo J, Argente J. Primary hypoaldosteronism and moder- ate bilateral deafness in a child with a homozygous missense mutation (Thr318Met) in the CYP11B2 gene. An Pediatr (Barc). $2010 ; 73(1): 31-4$

14. Üstyol A, Atabek ME, Taylor N, Yeung MC, Chan AO. Corticosterone methyl oxidase deficiency type 1 with normokalemia in an infant. J Clin Res Pediatr Endocrinol. 2016;8(3):356-9.

15. Wikiera B, GŁąb E, Barg E, Noczyńska A. Congenital hypoaldosteronism associated with nails hypothrophy - case report and review of the literature. Pediatr Endocrinol Diabetes Metab. 2008;14(4):253-6.

16. Rösler A. The natural history of salt-wasting disorders of adrenal and renal origin. J Clin Endocrinol Metab. 1984;59(4):689-700.

17. Rösler A, Rabinowitz D, Theodor R, Ramirez LC, Ulick S. The nature of the defect in a salt-wasting disorder in Jews of Iran. J Clin Endocrinol Metab. 1977;44(2):279-91.

18. Nomoto S, Massa G, Mitani F, Ishimura Y, Miyahara K, Toda K, et al. CMO I deficiency caused by a point mutation in exon 8 of the human CYP11B2 gene encoding steroid 18-hydroxylase (P450C18). Biochem Biophys Res Commun. 1997;234(2):382-5.

19. Pascoe L, Curnow KM, Slutsker L, Rösler A, White PC. Mutations in the human CYP11B2 (aldosterone synthase) gene causing corticosterone methyloxidase II deficiency. Proc Natl Acad Sci U S A. 1992;89(11):4996-5000.

20. Rainey WE. Adrenal zonation: clues from 11 beta-hydroxylase and aldosterone synthase. Mol Cell Endocrinol. 1999;151(1-2):151-60.

21. Dtattani MT, Gevers EF. Endocrinology of fetal development. In: Shlomo Melmed KSP, Larsen PR, Kronenberg HM, editors. Williams textbook of endocrinology. 13th ed. Philadelphia: Elsevier; 2016.

22. Freel EM, Ingram M, Wallace AM, White A, Fraser R, Davies $E$, et al. Effect of variation in CYP11B1 and CYP11B2 on corticosteroid phenotype and hypothalamic-pituitary-adrenal axis activity in hypertensive and normotensive subjects. Clin Endocrinol (Oxford). 2008;68(5):700-6.

23. Ulick S, Gautier E, Vetter KK, Markello JR, Yaffe S, Lowe CU. An aldosterone biosynthetic defect in a salt-losing disorder. J Clin Endocrinol Metab. 1964;24:669-72.

24. Baranowski ES, Arlt W, Idkowiak J. Monogenic disorders of adrenal steroidogenesis. Hormone Res. 2018;89(5):292-310.

25. Portrat-Doyen S, Tourniaire J, Richard O, Mulatero P, AupetitFaisant B, Curnow KM, et al. Isolated aldosterone synthase deficiency caused by simultaneous E198D and V386A mutations in the CYP11B2 gene. J Clin Endocrinol Metab. 1998;83(11): 4156-61. 